\section{Animal models of human retinal dystrophies}

retinal dystrophies in man occur as part of multi system diseases or syndromes such as Usher's syndrome and Norrie disease. There are animal models with similar multi-system involvement, one example being the tubby mouse $(t u b)$ that develops a syndromic disease characterised by retinal and cochlear degeneration as well as adult-onset obesity with insulin resistance and impaired glucose tolerance. ${ }^{1}$ Identification of the $t u b$ gene led to the recognition of a new family of genes, the human homologues of which are potential candidates for retinal dystrophies. $^{2}$ There are still several naturally occurring mouse models of retinal dystrophy that await molecular characterisation and may provide new candidate genes for human disease or, as was the case with the tubby mouse, lead to the identification of new families of genes. In addition to the spontaneous dystrophies the laboratory mouse offers the opportunity for genetic manipulation either by the introduction of a foreign gene (to create a transgenic animal) or by the targeted disruption of an endogenous gene (gene 'knock-out'). These techniques are powerful tools for the investigation of the retinal dystrophies as well as other diseases. Naturally occurring retinal dystrophies are recognised in other laboratory animals, for example the Royal College of Surgeons (RCS) rat which has been studied in detail, although the responsible gene mutation currently remains elusive.

Companion animals, particularly dogs, represent a diverse source of different models of retinal dystrophies. The most important group of conditions are the generalised progressive retinal atrophies (PRAs) (for a review see Petersen-Jones ${ }^{3}$ ). These inherited conditions all result in a progressive photoreceptor-led retinal degeneration resulting in similar clinical and ophthalmoscopic signs, but with varying ages at onset and rates of progression. Those forms that have been studied in detail can be divided into photoreceptor dysplasias or photoreceptor degenerations. With the dysplasias the photoreceptor development is abnormal or becomes halted in the immediate postnatal period when retinal maturation normally occurs. The dysplastic photoreceptors then progressively degenerate. With those forms of 
PRA classified as degenerations the photoreceptors appear to attain normal adult conformation but subsequently progressively degenerate. PRA has been described in over 100 different breeds of dog, only a small number of which have been studied in detail. Despite this, the breeding studies that have been performed have shown that there are several distinct forms of PRA. The majority of canine PRAs are recessively inherited although an X-linked form has been recognised in the Siberian husky and is the only animal model of X-linked retinitis pigmentosa. ${ }^{4}$ One form, a progressive rod-cone degeneration ( $p r c d)$, is present as an allelic condition in several breeds (miniature and toy poodle, English and American cocker spaniel, Labrador retriever and Portuguese water dog). Although the prcd gene has not been identified, recently genetic linkage to the locus was described. ${ }^{5}$ Rod-cone dysplasia type one $(r c d 1)$ in the Irish setter remains the only form of companion animal PRA for which the gene mutation has been identified (see Note added in proof). The mutation is in the cGMP phosphodiesterase beta subunit gene (PDE $\beta$ ). The same gene is mutated in the $r d$ mouse and also in some forms of retinitis pigmentosa as described in more detail in the following section.

PRA is less common in the cat than the dog. Two forms have been recognised and investigated in the Abyssinian cat. One form, which has a very early onset and rapid progression, is dominantly inherited and is the only companion animal model of autosomal dominant retinitis pigmentosa. The second form is recessively inherited and has a later onset of a slow, progressive rod-cone degeneration. This second form has similarities to pred in the poodle.

As well as PRA the dog also suffers from another group of progressive retinal diseases known as the retinal pigment epithelial dystrophies. In at least some of the affected breeds there would appear to be an inherited predisposition for the condition which is modified by an environmental factor. ${ }^{6}$ Unlike PRA the primary lesion is in the retinal pigment epithelium and is associated with lipofuscin deposition. ${ }^{7}$ Cone dysplasia has also been described in the dog, although it is very rare. A recent study of affected dogs showed an absence of cone outer segment beta 3-transducin immunoreactivity, making it a candidate gene for the defect. ${ }^{8}$ Congenital stationary night blindness occurs in animals as well as humans. It is described in the Appaloosa horse ${ }^{9}$ although the genetic defect has not been identified. In man several forms of CSNB are recognised and can result from mutations of the rod opsin, ${ }^{10} \mathrm{PDE},{ }^{11}$ rhodopsin kinase, ${ }^{12}$ alpha-1 transducin $^{13}$ and arrestin ${ }^{14}$ genes. We wait to find out whether the Appaloosa horse defect will prove to be a homologue of any of these defects. Retinal dystrophies have also been studied in a number of other species ranging from Drosophila to chickens, in which several forms are recognised, and primates, for example the Guinea baboon which suffers from a cone-rod dystrophy. ${ }^{15}$

\section{Retinal dystrophies of known genetic cause}

The genetic causes of a number of retinal dystrophies have been identified in man and fewer have been identified in animals. The following gives two examples where gene defects that are known to cause retinal dystrophies in man are also known to cause retinal dystrophies in animals. No doubt as further molecular studies of animal and human retinal dystrophies are performed more animal homologues of human disease will be identified.

\section{Cyclic GMP phosphodiesterase beta subunit (PDE $\beta)$ mutations}

The gene for PDE $\beta$, which encodes a member of the visual transduction cascade, is known to be mutated in retinal dystrophies of man, mouse and dog. The first discovery of a mutation in these gene was in the retinal degeneration $(r d)$ mouse. The $r d$ mouse has a very early onset of photoreceptor disease. Photoreceptors develop until about 10 days of age and then go on to degenerate rapidly such that by 20 days of age most photoreceptors are lost (with the exception of some cones). ${ }^{16}$ Studies have shown that there are elevations in retinal cGMP levels prior to retinal degeneration, ${ }^{17}$ and that this is associated with lowered cGMP phosphodiesterase activity. ${ }^{18}$ The defective gene was identified by Bowes et al. ${ }^{19}$ using a cDNA subtractive technique coupled with differential hybridisation. ${ }^{20,21}$ Two mutations were found in the $r d$ PDE $\beta$ gene. One is a nonsense mutation at codon $347^{22}$ that introduces a stop codon; the second is a retroviral element inserted in intron $1 .{ }^{23}$ Both mutations have been found in all strains of $r d$ mice. Further confirmation that the mutant $\mathrm{PDE} \beta$ gene was responsible for $r d$ was provided by introducing a normal copy of the gene into $r d$ mice and showing that the resulting transgenic mice did not develop retinal degeneration. ${ }^{24}$

The dog was the second animal species in which a retinal dystrophy causing mutation of the PDE $\beta$ gene was identified. A hereditary retinal degeneration had been recognised in the Irish setter breed of dog since the 1930s and reached a very high incidence in show dogs until a strict test-mating programme was introduced in the 1940s and 1950s. This form of PRA is known as rodcone dysplasia type one ( $r c d 1)$. Histopathological investigations showed that in $r c d 1$ the retina develops normally for the first 13 days of life after which photoreceptor differentiation becomes arrested. ${ }^{25}$ Biochemical analysis showed that coincidental with arrested photoreceptor development there is an abnormal elevation in retinal cGMP levels. The levels of cGMP continue to rise until they reach about ten times normal $^{26}$ and are associated with reduced cGMP phosphodiesterase activity. ${ }^{26,27}$ Investigations using Northern and slot blot analysis showed that the message for PDE $\beta$ was abnormally low before the retina degenerated. ${ }^{25}$ 
Cloning and sequencing of the PDE $\beta$ gene by two groups revealed the same mutation in $r c d 1$ Irish setters in the UK and USA. ${ }^{28,29}$ The mutation was a guanine-toadenine transition at nucleotide 2420 altering codon 807 from encoding tryptophan to a stop codon. Linkage studies confirmed that the mutation was the site of the rcd1 mutation. ${ }^{30}$

Screening of families with autosomal recessive retinitis pigmentosa revealed several with $\mathrm{PDE} \beta$ mutations that co-segregated with their disease status. $^{31-35}$ The affected patients were all compound heterozygotes for PDE $\beta$ mutations.

\section{Other animal models with cGMP accumulation}

Alteration of cGMP levels is a feature of other retinal dystrophies in animals. The collie dog suffers from a form of PRA very similar, but non-allelic, to $r c d 1 .{ }^{36}$ This is termed rod-cone dysplasia type two $(r c d 2)$. With $r c d 2$ there is a very early arrest of photoreceptor development with an almost complete failure of rod outer segment morphogenesis, ${ }^{37}$ and photoreceptor cell bodies go on to degenerate rapidly. There is an earlier and slightly greater elevation of retinal cGMP in $r c d 2$ compared with $r c d 1 .{ }^{38}$ Molecular investigations have excluded $\alpha 1$ transducin ${ }^{39}$ as the $r c d 2$ locus and have failed to find any sequence differences in the coding region of the genes for cGMP phosphodiesterase $\alpha, \beta$ and $\gamma$ subunits. ${ }^{40-42}$

The Labrador retriever in Scandinavia suffers from a photoreceptor dystrophy. Biochemical studies have demonstrated slightly raised levels of cGMP at early stages of retinal differentiation, although unlike in $r c d 1$, cGMP phosphodiesterase catalytic activity appeared normal. $^{43}$

Abyssinian cats with an autosomal dominant earlyonset form of PRA given the gene symbol $R d y$ are also reported to exhibit increased cGMP levels early in the disease process. $^{44}$

\section{Peripherin/RDS associated diseases}

The retinal degeneration slow ( $r d s)$ mouse phenotype is the result of a mutation in the peripherin/RDS gene. The $r d s$ mouse was first reported by Van Nie et al ${ }^{45}$ in 1978 and suffers from a semi-dominant disease characterised by photoreceptor dysplasia followed by degeneration. Mice heterozygous for the mutation $(r d s /+)$ develop dysplastic photoreceptor outer segments, which then very slowly degenerate. The homozygous $(r d s / r d s)$ mice have a more severe phenotype: they fail to produce any outer segments, and photoreceptor degeneration is apparent by 3 weeks of age.

Identification of the $r d s$ gene was achieved using a combination of subtractive and differential hybridisation methods. ${ }^{46,47}$ The gene identified was the peripherin/ RDS (or peripherin 2) gene which encodes a structural protein present in photoreceptor outer segments. ${ }^{48,49}$ The $r d s$ mutation is due to a $9.2 \mathrm{~kb}$ insertion of foreign DNA into exon two of the gene creating a null mutation. ${ }^{50,51}$ Final confirmation that the peripherin/RDS mutation wsa responsible for the $r d s$ phenotype was provided by construction of transgenic $r d s$ mice in which a normal peripherin/RDS gene was expressed and resulted in photoreceptor cell rescue. ${ }^{52}$ The semidominant nature of the $r d s$ mutations is thought to be due to haplotype insufficiency. Heterozygous affected animals have a single functional copy of the gene that does not make sufficient product to prevent a slow retinal degeneration. The homozygous affected mice have a complete absence of the protein and develop a much more severe phenotype.

Following identification of peripherin/RDS, screening of the gene in human patients with retinal dystrophies has led to the identification of over 40 different mutations within the gene. ${ }^{53}$ It is interesting to note that these mutations result in a wide range of phenotypes. Some phenotypes show more severe rod dysfunction, as is typical of classical autosomal dominant retinitis pigmentosa; others predominantly have cone disease with rods affected to a lesser extent (for example, cone-rod dystrophies); and others result in macular dystrophies.

\section{Benefits of animal models of retinal dystrophies}

Studies of animal models of human retinal dystrophies offer many obvious benefits. Molecular investigations can yield new potential candidate genes for human disease or even lead to the identification of previously unrecognised retinal genes. Detailed histopathological, molecular and electrophysiological studies impossible in human patients can be undertaken in animal models and contribute to the understanding of disease mechanisms in the retina. The animal homologues of human disease can be used for the investigation of drug treatment or gene therapy, with the aim of preventing or slowing down photoreceptor degeneration. Initial work in the mouse is attractive because of the relative cheapness, short generation interval and well-characterised genetics. However, the eye of the mouse is unlike the human eye in its physical size and rod-to-cone ratio. Larger animal models should prove useful as intermediate models between mouse and human eyes. For example, therapy to treat PDE $\beta$ defects could initially be undertaken in the $r d$ mouse and promising therapies then refined by experiments using the $r c d 1$ dog before considering human clinical trials.

Animal models of retinal dystrophies are an important resource that requires detailed study.

\section{Note added in proof}

Subsequent to the submission of this paper a PRAcausing mutation has been identified in the gene encoding the alpha subunit of cGMP phosphodiesterase in the Cardigan Welsh corgi breed of dog (Petersen-Jones SM, Entz D, Sargan DR. Mutation linked to cGMPphosphodiesterase alpha gene causes generalized progressive retinal atrophy in the Cardigan Welsh corgi. Invest Ophthal Vis Sci (Suppl) 1998;39:4081). 


\section{References}

1. Noben-Trauth K, Naggert JK, North MA, Nishina PM. A candidate gene for the mouse mutation tubby. Nature 1996;380:534-8.

2. North MA, Naggert JK, Yan Y, Noben-Trauth K, Nishina P. Molecular characterization of the TUB, TULP1 and TULP2, members of the novel tubby gene family, and their possible relation to ocular diseases. Proc Natl Acad Sci USA 1997;94:3128-33.

3. Petersen-Jones SM. A review of research to elucidate the causes of generalized progressive retinal atrophies. Vet J 1998;155:5-18.

4. Acland GM, Blanton SH, Hershfield B, Aguirre GD. Xlpra: a canine retinal degeneration inherited as an X-linked trait. Am J Med Genet 1994;52:27-33.

5. Gu W-K, Acland GM, Ray K, Aguirre GD. Identification of a RAPD marker linked to progressive rod-cone degeneration. Invest Ophthalmol Vis Sci (Suppl) 1997;38:1510.

6. Bedford PGC. Retinal pigment epithelial dystrophy (CPRA): a study of the disease in the briard. J Small Anim Pract 1984;25:129-38.

7. Watson P, Wrigstad A, Riis RC, Narfström K, Bedford PGC, Nilsson SEG. Retinal degenerations in briard dogs. In: Hollyfield JG, LaVail MM, Anderson RE, editors. Retinal degeneration: clinical and laboratory applications. New York: Plenum Press, 1993:281.

8. Gropp KE, Szel A, Huang JC, Acland GM, Farber DB, Aguirre GD. Selective absence of cone outer segment beta 3transducin immunoreactivity in hereditary cone degeneration (cd). Exp Eye Res 1996;63:285-96.

9. Witzel DA, Smith EL, Wilson RD, Aguirre GD. Congenital stationary night blindness: an animal model. Invest Ophthalmol Vis Sci 1978;17:788-95.

10. Dryja TP, Berson EL, Rao VR, Oprian DD. Heterozygous missense mutation in the rhodopsin gene as a cause of congenital stationary night blindness. Nature Genet 1993;4:280-3.

11. Gal A, Orth U, Baehr W, Schwinger E, Rosenberg T. Heterozygous missense mutation in the rod cGMP phosphodiesterase $\beta$-subunit gene in autosomal dominant stationary night blindness. Nature Genet 1994;7:64-8.

12. Yamamoto S, Sippel C, Berson EL, Dryja TP. Defects in the rhodopsin kinase gene in the Oguchi form of stationary night blindness. Nature Genet 1997;15:175-8.

13. Dryja TP, Hahn LB, Reboul T, Arnaud B. Missense mutation in the gene encoding the $\alpha$ subunit of rod transducin in the Nougaret form of congenital stationary night blindness. Nature Genet 1996;13:358-60.

14. Fuchs S, Nakazawa M, Maw M, Tamai M, Oguchi Y, Gal A. A homozygous 1-base pair deletion in the arrestin gene is a frequent cause of Oguchi disease in Japanese. Nature Genet 1995;10:360-2.

15. Vainisi SJ, Fishman GA, Wolf ED, Boese GK. Cone-rod dystrophy in the Guinea baboon. Trans Am Acad Ophthalmol Otolaryngol 1976;81:OP725-30.

16. LaVail MM, Sidman RL. Retinal degeneration in the mouse. Arch Ophthalmol 1974;91:394-400.

17. Farber DB, Lolley RN. Cyclic guanosine monophosphate: elevations in degenerating photoreceptor cells of the $\mathrm{C} 3 \mathrm{H}$ mouse retina. Science 1974;186:449-51.

18. Farber DB, Park S, Yamashita C. Cyclic GMPphosphodiesterase of $r d$ retina: biosynthesis and content. Exp Eye Res 1988;46:363-74.

19. Bowes C, Danciger M, Kozak CA, Farber DB. Isolation of a candidate cDNA for the gene causing retinal degeneration in the $r d$ mouse. Proc Natl Acad Sci USA 1989;86:9722-6.

20. Farber DB, Bowes C, Danciger M. Studies leading to the isolation of a cDNA for the gene causing retinal degeneration in the $r d$ mouse. Prog Clin Biol Res 1991;362:67-86.
21. Bowes C, Li T, Danciger M, Baxter LC, Applebury ML, Farber DB. Retinal degeneration in the $r d$ mouse is caused by a defect in the $\beta$ subunit of rod cGMP-phosphodiesterase. Nature 1990;347:677-80.

22. Pittler SJ, Baehr W. Identification of a nonsense mutation in the rod photoreceptor cGMP phosphodiesterase $\beta$-subunit gene of the $r d$ mouse. Proc Natl Acad Sci USA 1991;88:8322-6.

23. Bowes C, Li T, Frankel WN, Danciger M, Coffin J, Applebury ML, Farber DB. Localisation of a retroviral element within the $r d$ gene coding of the $\beta$ subunit of cGMP phosphodiesterase. Proc Natl Acad Sci USA 1993;90:2955-9.

24. Lem J, Flannery JG, Li T, Applebury ML, Farber DB. Retinal degeneration is rescued in transgenic $r d$ mice by expression of the cGMP phosphodiesterase $\beta$ subunit. Proc Natl Acad Sci USA 1992;89:4422-6.

25. Farber DB, Danciger JS, Aguirre G. The beta subunit of cyclic GMP phosphodiesterase mRNA is deficient in canine rod-cone dysplasia 1. Neuron 1992;9:349-56.

26. Aguirre GD, Farber D, Lolley R, Fletcher RT, Chader GJ. Rod-cone dysplasia in Irish setters: a defect in cyclic GMP metabolism in visual cells. Science 1978;201:1133-4.

27. Liu YP, Krishna G, Aguirre G, Chader G. Involvement of cyclic GMP phosphodiesterase activator in an hereditary retinal degeneration. Nature 1979;280:62-4.

28. Suber ML, Pittler SJ, Quin N, Wright GC, Holcombe N, Lee $\mathrm{RH}$, et al. Irish setter dogs affected with rod-cone dysplasia contain a nonsense mutation in the rod cGMP phosphodiesterase beta-subunit gene. Proc Natl Acad Sci USA 1993;90:3968-72.

29. Clements PJM, Gregory CY, Petersen-Jones SM, Sargan DR, Bhattacharya SS. Confirmation of the rod cGMP phosphodiesterase $\beta$-subunit (PDE $\beta$ ) nonsense mutation in affected $r c d-1$ Irish setters in the UK and development of a diagnostic test. Curr Eye Res 1993;12:861-6.

30. Ray K, Baldwin VJ, Acland GM, Blanton SH, Aguirre GD. Cosegregation of codon 807 mutation of the canine rod cGMP phosphodiesterase $\beta$ gene and $r c d 1$. Invest Ophthalmol Vis Sci 1994;35:4291-9.

31. McLaughlin ME, Sandberg MA, Berson EL, Dryja TP. Recessive mutations in the gene encoding the $\beta$-subunit of rod phosphodiesterase in patients with retinitis pigmentosa. Nature Genet 1993;4:130-4.

32. Danciger M, Blaney J, Gao YQ, Zhao DY, Heckenlively JH, Weleber RG, et al. Haplotype analysis of small RP families for five gene loci: recessive mutations in the $P D E \beta$ gene. Invest Ophthalmol Vis Sci (Suppl) 1995;36:3816.

33. McLaughlin ME, Ehrhart TL, Sandberg MA, Berson EL. Mutations in the beta subunit of rod phosphodiesterase in patients with autosomal recessive retinitis pigmentosa. Invest Ophthalmol Vis Sci (Suppl) 1994;35:2162.

34. Farber DB, DiPolo A, Danciger M. New insights into the normal and abnormal expression of the human beta-PDE gene [abstract]. VI International Symposium on Retinal Degeneration, Jerusalem, Israel, 1994.

35. McLaughlin ME, Ehrhart TL, Berson EL, Dryja TP. Mutation spectrum of the gene encoding the beta subunit of rod phosphodiesterase among patients with autosomal recessive retinitis pigmentosa. Proc Natl Acad Sci USA 1995;92:3249-53.

36. Acland GM, Fletcher RT, Gentleman S, Chader GJ, Aguirre GD. Non-allelism of three genes ( $r c d 1, r c d 2$ and $e r d)$ for earlyonset hereditary retinal degeneration. Exp Eye Res 1989;49:983-98.

37. Santos-Anderson RM, Tso M, Wolf ED. An inherited retinopathy in collies: a light and electron microscopic study. Invest Ophthalmol Vis Sci 1980;19:1282-94.

38. Woodford BJ, Liu Y, Fletcher RT, Chader GJ, Farber DB, Santos-Anderson R. Tso MOM. Cyclic nucleotide metabolism in inherited retinopathy in collies; a biochemical and histochemical study. Exp Eye Res 1982;34:703-14. 
39. Ray K, Zeiss C, Acland GM, Aguirre GD. Exclusion of $\alpha 1-$ transducin gene as a candidate from four non-allelic forms of canine progressive retinal atrophy. Invest Ophthalmol Vis Sci (Suppl) 1996;37:4558.

40. Wang W, Acland GM, Aguirre GD, Ray K. Canine rod specific cGMP phosphodiesterase $\gamma$-subunit (PDEG) gene and its role in rod-cone dysplasia type2 (RCD2). Invest Ophthalmol Vis Sci (Suppl) 1996;37:4559.

41. Wang W, Acland GM, Aguirre GD, Ray K. Cloning and characterization of the cDNA encoding the alpha-subunit of cGMP-phosphodiesterase in canine retinal rod photoreceptor cells. Molecular Vision (http: / / www emory edu/ Molecular_Vision/index html) 1996;2.

42. Wang W, Acland GM, Aguirre GD, Ray K. Probable exclusion of 3 subunits of canine rod specific cGMP phosphodiesterase as candidates for rod-cone dysplasia type 2 (rcd2). Invest Ophthalmol Vis Sci (Suppl) 1997;38:1515.

43. Kommonen B, Kylma T, Cohen RJ, Penn JS, Paulin L. Hurwitz MY, Hurwitz RL. Elevation of cGMP with normal expression and activity of rod cGMP-PDE in photoreceptor degenerate Labrador retrievers. Vision Res 1996;28:19-28.

44. Hussain AA, Leon A, Curtis R, Barnett KC. Photoreceptor dysplasia in the Abyssinian cat: biochemical and electrophysiological evidence for abnormal cyclic nucleotide metabolism. Biochem Soc Trans 1989;17:221-2.

45. Van Nie R, Ivanyi D, Demant P. A new H-2 linked mutation, $r d s$, causing retinal degeneration in the mouse. Tissue Antigens 1978;12:106-8.
46. Travis GH, Brennan MB, Danielsen PE, Kozak CA, Sutcliffe JG. Identification of a photoreceptor-specific mRNA encoded by the gene responsible for retinal degeneration slow $(r d s)$. Nature 1989;338:70-3.

47. Connell GJ, Molday RS. Molecular cloning, primary structure, and orientation of the vertebrate photoreceptor cell protein peripherin in the rod outer segment disk membrane. Biochemistry 1990;29:4691-8.

48. Connell G, Bascom R, Molday L, Reid D, McInnes RR, Molday RS. Photoreceptor peripherin is the normal product of the gene responsible for retinal degeneration in the $r d s$ mouse. Proc Natl Acad Sci USA 1991;88:723-6.

49. Travis GH, Sutcliffe JG, Bok D. The retinal degeneration slow $(r d s)$ gene product is a photoreceptor disc membraneassociated glycoprotein. Neuron 1991;6:61-70.

50. Norton JC, Allen AC, Burns JE, Sutcliffe JG, Travis GH. Finestructure analysis of the mouse retinal degeneration slow ( $r d s)$ mutant locus. Invest Ophthalmol Vis Sci (Suppl) 1994;35:1464.

51. Ma J, Norton JC, Allen JC, Burns JB, Hasel KW, Burns JL, et al. Retinal degeneration slow $(r d s)$ in mouse results from simple insertion of a t haplotype-specific element into protein-coding exon II. Genomics 1995;28:212-9.

52. Travis GH, Groshan KR, Lloyd M, Bok D. Complete rescue of photoreceptor dysplasia and degeneration in transgenic retinal degeneration slow ( $r d s)$ mice. Neuron 1992;9:113-9.

53. Keen TJ, Inglehearn CF. Mutations and polymorphisms in the human peripherin/rds gene and their involvement in inherited retinal degeneration. Hum Mut 1996;8:297-303. 